\title{
Pilot study of salbutamol in the treatment of acute asthma - Little apparent benefit to dose and frequency adjustments
}

\author{
DOUGLAS SINCLAIR MD, MG MACKENZIE PhD, DENNIS M BOWIE MD \\ Queen Elizabeth II Health Sciences Centre, Halifax, Nova Scotia
}

D Sinclair, MG MacKenzie, D Bowie. Pilot study of salbutamol in the treatment of acute asthma - Little apparent benefit to dose and frequency adjustments. Can Respir J 1997;4(1):41-44.

STUDY OBJECTIVE: To compare two dosing regimens of salbutamol in acute asthma.

DESIGN: Prospective randomized double-blind trial.

SETTING: Urban emergency department.

TYPE OF PARTICIPANTS: Patients who presented to the emergency department with moderate to severe asthma. INTERVENTIONS: All patients had pulmonary function testing and were randomized to group $\mathrm{A}($ control; $\mathrm{n}=25$ ) or group B (experimental; $n=23$ ). Group A (control) patients received salbutamol $2.5 \mathrm{mg}$ delivered by wet aerosol at 0,1 and $2 \mathrm{~h}$ (total dose $7.5 \mathrm{mg}$ ). At 20, 40, 80 and 100 mins a placebo aerosol was given. Group B patients received salbutamol $5 \mathrm{mg}$ at $0 \mathrm{~min}$ and one-third the initial dose every 20 mins for a total of six doses by wet aerosol (total dose 15 $\mathrm{mg})$.

RESULTS: There were no differences in age, sex, preadmission medications or initial forced expiratory volume in $1 \mathrm{~s}\left(\mathrm{FEV}_{1}\right)$ between the groups. Forty-eight patients completed the study. Both groups of patients improved with mean absolute change in $\mathrm{FEV}_{1}$ of $700 \mathrm{~mL}$ in group $\mathrm{A}$ and $590 \mathrm{~mL}$ in group B. There were no statistical differences between the two groups in terms of treatment response, admission rates or side effects.
CONCLUSIONS: This study of patients presenting with acute asthma demonstrated no differences in improvement during the initial $3 \mathrm{~h}$ of treatment with a standard dose of aerosolized salbutamol given at hourly intervals (total dose $7.5 \mathrm{mg}$ ) compared with a higher total dose given at $20 \mathrm{~min}$ intervals (total dose $15 \mathrm{mg}$ ).

Key Words: Aerosol, Asthma, Dose adjustments, Salbutamol

Étude pilote sur le salbutamol pour le traitement de l'asthme aigu - Peu d'avantages apparents liés à l'ajustement des doses et de la fréquence d'administration

OBJECTIF DE l'ÉTUDE: comparer deux schémas posologiques de salbutamol pour le traitement de l'asthme aigu. MODÈLE: Essai prospectif à double insu randomisé. CONTEXTE: Service des Urgences en milieu urbain. TYPE DES PARTICIPANTS: Patients qui se sont présentés aux Urgences, et qui souffraient d'un asthme modéré à grave.

INTERVENTIONS: Tous les patients ont subi des épreuves de fonction respiratoire et ont été randomisés dans le groupe A (témoin; $n=25$ ) ou dans le groupe $B$ (expérimental; $n=23$ ). Les patients du groupe témoin ont reçu du salbutamol à raison de 2,5 mg en aérosol à 0,1 et $2 \mathrm{~h}$ (dose totale de $7,5 \mathrm{mg}$ ). À $20,40,80$ et 100 minutes, ces patients ont reçu un placebo en aérosol. Les patients du groupe expérimental ont reçu du salbutamol à raison de $5 \mathrm{mg}$ à $0 \mathrm{~min}$ et un tiers de la dose initiale toutes les 20 minutes jusqu'à un total de six doses en aérosol (dose totale de $15 \mathrm{mg}$ ).

RÉSULTATS: On a noté aucune différence entre les deux groupes 
relativement à l'âge, le sexe, les médicaments administrés avant l'admission ou le volume expiratoire maximum/seconde (VEMS) moyen initial. Quarante-huit patients ont complété l'étude. Les deux groupes de patients ont amélioré leur VEMS avec un changement moyen absolu de $700 \mathrm{~mL}$ dans le groupe A et de $590 \mathrm{~mL}$ dans le groupe B. On a noté aucune différence statistique entre les deux groupes pour ce qui est de la réponse au traitement, du taux d'admission ou des effets secondaires.

CONCLUSIONS: La présente étude sur des patients accusant un asthme aigu n'a démontré aucune différence dans l'amélioration de leur état pendant les trois premières heures de traitement avec une dose normale de salbutamol en aérosol administrée toutes les heures (dose totale de 7,5 mg) comparativement à une dose totale plus élevée administrée toutes les $20 \mathrm{~min}$ (dose totale de $15 \mathrm{mg}$ ).
$\mathrm{T}$ he treatment of the asthmatic patient in the emergency department is often a challenging problem because a number of therapies are available. In the asthmatic patient presenting acutely, the initial drug of choice is a beta-agonist (1). This is used over other drugs because of its early onset, reaching a peak effect 15 to 45 mins after initiation $(2,3)$.

While there is widespread agreement on the indications for use of a beta-agonist in the acute therapy of asthma, there is much controversy on the dose, frequency and route of administration (4). Recently predose nebules of salbutamol have become available containing $2.5 \mathrm{mg}$ of salbutamol in $2.5 \mathrm{~mL}$ of total solution. It was our hypothesis that larger doses of aerosolized salbutamol should result in greater bronchodilation as has been shown in more stable asthma patients (5). The following study was designed to evaluate two dosing regimens of salbutamol delivered via a wet aerosol in the treatment of acutely ill asthma patients in the emergency department.

\section{PATIENTS AND METHODS}

A prospective double-blind study was conducted over a six-month period in 1990 in the emergency department of Victoria General Hospital, Halifax, Nova Scotia, a 600-bed adult tertiary care facility with an emergency census of 46,000 patient-visits per year. Any adult patient over 18 years of age who presented to the emergency department with an acute episode of asthma as defined by the American Thoracic Society (6) was eligible for study. Patients were excluded if they had ischemic heart disease; allergy to salbutamol; evidence of arrythmia; history of chronic obstructive lung disease; a requirement for intubation; were pregnant; were older than 75 years; or were unable to cooperate for pulmonary function testing. Informed consent was obtained before study enrolment.

Patients were under the care of emergency physicians who were able to select any other adjunctive therapy during the

TABLE 1

Clinical characteristics of patients

\begin{tabular}{lccc}
\hline & Group A & Group B & P value \\
\hline Mean age (years) & 33.2 & 38.5 & $\mathrm{NS}$ \\
Sex (male/female) & $7 / 18$ & $7 / 16$ & $\mathrm{NS}$ \\
& Medication preadmission & \\
Theophylline & 12 & 12 & $\mathrm{NS}$ \\
Beta-agonist & 25 & 22 & $\mathrm{NS}$ \\
Ipratropium & 3 & 3 & $\mathrm{NS}$ \\
Initial FEV $^{*}$ & $1.16 \pm 0.54$ & $1.16 \pm 0.65$ & $\mathrm{NS}$ \\
Total $^{*}$ & 25 & 23 & \\
\hline
\end{tabular}

${ }^{*}$ Mean \pm SEM. FEV 1 Forced expiratory volume in $1 \mathrm{~s}$; NS Not significant study period except other aerosolized medication. All drugs were prepared in the hospital pharmacy to achieve randomized double-blinding.

At presentation, all patients had pulmonary function testing (forced expiratory volume in $1 \mathrm{~s}\left[\mathrm{FEV}_{1}\right]$, peak expiratory flow rate, forced vital capacity) completed by a respiratory therapist, based on the best of three attempts. Initial assessment was completed, and patients were assigned to group A or B. Group A patients received salbutamol $2.5 \mathrm{mg}$ premixed with $3.5 \mathrm{~mL}$ of saline and delivered by an aerosol from a 'power mist' nebulizer (Hospitak USA, location?), at a flow rate of $6 \mathrm{~L}$ of oxygen per minute at time 0,1 and $2 \mathrm{~h}$. At 20, 40, 80 and 100 mins, a placebo saline aerosol was given. The total dose of salbutamol given was $7.5 \mathrm{mg}$.

Group B patients received salbutamol $5 \mathrm{mg}$ at $0 \mathrm{~min}$ and one-third of the dose mixed with normal saline every 20 mins for a total of six doses. The total dose of salbutamol given was $15 \mathrm{mg}$. All aerosols were premixed to a total volume of $4 \mathrm{~mL}$. Measurement of vital signs was carried out after each dose of medication, and assessment of accessory muscle use and classification of wheezing as mild/moderate/severe was performed. At the conclusion of the study period, pulmonary function studies were repeated. Further therapy was initiated as required, and the patient was either admitted to hospital or discharged from the emergency department with follow-up instructions. Patients were contacted within 10 days of hospital discharge to determine medication side effects and evidence of relapse or admission to hospital. Specific side effects monitored included tremor, palpitations, irritability, nausea and vomiting. Results were analyzed using Student's $t$ test or $\chi^{2}$ as appropriate.

\section{RESULTS}

Fifty-nine patients were initially eligible for study. Two patients were excluded because they had evidence of chronic obstructive lung disease; four patients improved during the

\section{TABLE 2}

\section{Study results}

\begin{tabular}{lccc}
\hline & Group A & Group B & P value \\
\hline${\text { Post-treatment } \mathrm{FEV}_{1}{ }^{*}}^{*}$ & $1.86 \pm 0.6$ & $1.75 \pm 0.51$ & $\mathrm{NS}$ \\
${\text { Change in } \mathrm{mL}^{*}}$ & $700 \pm 630$ & $590 \pm 520$ & $\mathrm{NS}$ \\
Percentage change & $67.8 \pm 53.6$ & $74.5 \pm 81.7$ & $\mathrm{NS}$ \\
Admission & 6 & 4 & $\mathrm{NS}$ \\
Relapse & 1 & 1 & $\mathrm{NS}$ \\
Discharged on steroids & 12 & 10 & $\mathrm{NS}$ \\
\hline
\end{tabular}

${ }^{*}$ Mean \pm SEM. FEV 1 Forced expiratory volume in $1 \mathrm{~s}$; NS Not significant 
study period and did not complete the protocol; data was incomplete on four patients; and one patient did not complete the study due to nausea. Forty-eight patients were thus available for study. Both group A and B patients were similar with respect to age, sex distribution, duration of asthma, regular medications and initial FEV 1 (Table 1).

At the completion of the study, both groups of patients had improved with a mean absolute change in $\mathrm{FEV}_{1}$ of $700 \mathrm{~mL}$ $(67.8 \%)$ in group A and $590 \mathrm{~mL}(74.5 \%)$ in group B. Because of the wide variation of response to medication, there was no statistical difference between high and low dose therapy. There were no differences between the groups with respect to other drugs given during the emergency department visit. The incidence of side effects and number of patients admitted to hospital or returning to the emergency department was not significantly different between the two groups. Twelve patients in group A and 10 patients in group B were discharged from the emergency department on a short course of oral steroids (Tables 2,3).

\section{DISCUSSION}

This study has shown no difference in the improvement of acute asthma in patients treated for $3 \mathrm{~h}$ either with a standard dose $(2.5 \mathrm{mg})$ of aerosolized salbutamol given at hourly intervals (total dose $7.5 \mathrm{mg}$ ) or a higher total dose administered more frequently, every $20 \mathrm{mins}$ (total dose $15 \mathrm{mg}$ ). Both dose regimens improved $\mathrm{FEV}_{1}$ by $60 \%$ to $70 \%$ with a low incidence of side effects and an acceptable rate of relapse of therapy and hospital admission. There were no deaths in the study.

Other studies have been conducted to determine the dose of a beta-agonist for acute asthma. Robertson et al (7) used a 20-minute dosing interval versus the standard $1 \mathrm{~h}$ interval with the same total dose of salbutomol in pediatric patients and found a $48 \%$ improvement in $\mathrm{FEV}_{1}$ in the frequent dose group. Nelson et al (8) studied acute adult asthma patients in the emergency department, comparing aerosolized metaproterenol $(0.3 \mathrm{~mL})$ delivered every $20 \mathrm{mins}$ for a total of three doses, with a single dose of metaproterenol followed by two saline aerosols. There was an improved response in the split dose group as measured by the $\mathrm{FEV}_{1}$ at 60 and $120 \mathrm{~min}$ without any change in side effects.

Horn et al (9) were able to show the value of high dose inhaled therapy in stable asthmatics. Therapy was increased from salbutamol $400 \mu \mathrm{g}$ qid via rotahaler to $2000 \mu \mathrm{g}$ qid. All chronic symptoms were abolished, and the number of acute attacks was reduced. Bellamy and Penketh (10) compared salbutamol with fenoterol in stable asthmatics. They showed a greater degree of bronchodilation with increasing doses over the range of two, four and six puffs delivered by metered dose inhaler (MDI). They suggested that six puffs of salbutamol was an effective dose and free from major side effects.

Other investigators have shown different results. Bardin and Joubert (11) compared high dose $(1000 \mu \mathrm{g})$ with conventional dose $(200 \mu \mathrm{g})$ salbutamol delivered by MDI in stable asthmatics. They did not show any difference in bronchodilator effect or side effects. Lipworth et al (12) studied 14
TABLE 3

Patient side effects

\begin{tabular}{lcc}
\hline & Group A & Group B \\
\hline Tachycardia & 2 & 2 \\
Tremor & 2 & 3 \\
Headache & 1 & 2 \\
Nausea & 3 & 2 \\
\hline
\end{tabular}

stable asthmatics with cumulative doubling doses of salbutamol by MDI of 100, 200, 500, 1000, 2000 and $4000 \mu \mathrm{g}$. They showed an increased bronchodilator effect at high doses, but there was great individual variation and some patients with severe asthma did not respond. Lin et al (13) and Rudnitsky et al (14) compared the effect of albuterol given by continuous or intermittent nebulization and found no difference in clinical effect or side effects in adult patients with exacerbations of asthma.

Regular use of beta-agonist drugs in stable asthma patients has been suggested as a cause of the increase in mortality recently observed (15). Some authors think the etiology for this may be the hypokalemic effect of beta-agonists and the production of a lethal arrythmia $(16,17)$. With the use of high dose beta-agonist therapy in acute asthma becoming widespread, concern is being raised that this may be an unsafe practice. Gilmartin et al (18) monitored asthmatic patients receiving salbutamol by home aerosols (total dose 10 to $17.5 \mathrm{mg}$ per $24 \mathrm{~h}$ ) with Holter monitors. No arrythmias were noted. Newhouse et al (19) compared acute asthma patients using fenoterol and salbutamol delivered by MDI. No clinically significant arrythmias, hypokalemia or prolongation of QT was noted.

Our study shows no significant difference in the amount of bronchodilation between high dose salbutamol (15 mg) and the lower dose of $7.5 \mathrm{mg}$ given less often, which is in contrast to Robertson and colleagues (7). The reasons for this may be that the numbers were too small or that the $7.5 \mathrm{mg}$ dose was sufficient to achieve maximum bronchodilation. We calculated that to detect a $20 \%$ difference between the two groups, we would need 377 patients in each treatment arm. Secondly, we cannot rule out an effect of nebulizer output as suggested by Alvine et al (20). However, we used the same nebulizer with the same amount of fluid $(4 \mathrm{~mL})$ throughout the study. Given that there was a significant bronchodilation in each group and that each group received no other treatment, we do not think nebulizer output influenced the results.

\section{CONCLUSIONS}

This study has shown no differences or improvement of acute asthma treated with a standard dose of aerosolized salbutamol given at hourly intervals compared with a higher total dose and more frequent administration (every 20 mins).

Further studies are required to determine the safety of high dose beta-agonist therapy in the severe acute asthma patient and the optimal total dose and interval to achieve maximum therapeutic benefit. 
ACKNOWLEDGEMENT: The authors thank Dr P Roy for his assistance with this study and the support of Glaxo Canada.

\section{REFERENCES}

1. Woodhead M. Guidelines on the management of asthma. Thorax 1993;48(Suppl):S1-24.

2. Rossing TM, Fanta CH, Goldstein DH, Snapper JR, McFadden ER. Emergency therapy of asthma: Comparison of the acute effects of parenteral and inhaled sympathomimetics and infused aminophyline. Am Rev Respir Dis 1980;122:365-71.

3. Lloyd SR, Sharma A. Aminophyline infusion in severe asthma: Where do we go from here? Can Fam Phys 1990;36:917-9.

4. Colacone A, Afilalo M, Walkove N, Kreisman M. A comparison of albuterol administered by metered dose inhibitor (and holding chamber) or wet nebulizer in acute asthma. Chest 1993;104:835-41.

5. Lipworth BJ, Struthers AD, McDevitt DG. Tachyphylaxis to systemic but not to airway responses during prolonged therapy with high dose inhaled salbutamol in asthmatics. Am Rev Respir Dis 1989;410:586-92.

6. American Thoracic Society. Standards for the diagnosis and care of patients with chronic obstructive pulmonary disease (COPD) and asthma. Am Rev Respir Dis 1987;136:225-44.

7. Robertson CF, Smith F, Beck R, Levison H. Response to frequent low doses of nebulized salbutamol in acute asthma. J Pediatr 1985;106:627-74.

8. Nelson MS, Hofstadter A, Parker A, Hargis C. Frequency of inhaled metaproterenol in the treatment of acute asthma exacerbation. Ann Emerg Med 1990;19:21-5.

9. Horn CR, Clark TJH, Cochrane GM. Can the morbidity of asthma be reduced by high dose inhaled therapy? A prospective study. Respir Med 1990;84:61-6.

10. Bellamy D, Penketh A. A cumulative dose comparison between salbutamol and fenoterol metered dose aerosols in asthmatic patients. Postgrad Med J 1987;63;459-61.

11. Bardin PG, Joubert JR. Inhaled beta stimulants: A study of high dose versus conventional dose treatment in asthmatic outpatients. S Afr Med J 1991;79:655-9.

12. Lipworth BJ, Clark RA, Dhillon DP, Brown RA, McDevitt DG. $\beta_{2}$-adrenoceptor response to high doses of inhaled salbutamol in patients with bronchial asthma. Br J Clin Pharmacol 1988;26:527-33

13. Lin RY, Sauter D, Neuman T, Sirlent J, Walters J, Tavakol M. Continuous versus intermittent albuterol nebulization in the treatment of asthma. Ann Emerg Med 1993;22:1847-53.

14. Rudintsky GS, Eberlein RS, Schotstall JM, Mazur JE, Spivey WH. Comparison of intermittent and continuously nebulized albuterol for treatment of asthma in an urban emergency department. Ann Emerg Med 1993;22:1842-6.

15. Windom HH, Burgess CD, Siebess RWL, et al. The pulmonary and extrapulmonary effects of inhaled $\beta_{2}$-agonist in patients with asthma. Clin Pharmacol Ther 1990;48:296-301.

16. Wong CS, Pavord ID, Williams J, Britton JR, Tatterrsfield AE. Bronchodilator cardiovascular and hypokalemic effects of fenoterol, salbutamol and terbutaline in asthma. Lancet 1990;336:1396-9.

17. Bodenhamer J, Bergström RB, Brown D, Gabow P, Marx JA, Lowenstein SR. Frequently nebulized $\beta_{2}$-agonists for asthma: Effects on serum electrolytes. Ann Emerg Med 1993;21:1337-42.

18. Gilmartin JJ, Veale D, Murray A, Adams PC, Gibson GJ. Cardiac effects of salbutamol given by air driven nebuliser at home. Thorax 1986;41:331-2.

19. Newhouse MT, McCallum AL, Abboud PT, et al. A multicentre clinical trial to compare the safety profiles of fenoterol MDI and albuterol MDI in acute severe asthmatics treated in the emergency room. Am Rev Respir Dis 1993;147:A57. (Abst)

20. Alvine GF, Rodgers P, Fitzsimmons KM, Ahrens RC. Disposable jet nebulizers; How reliable are they? Chest 1992;101:316-9. 


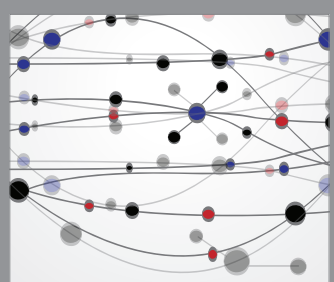

The Scientific World Journal
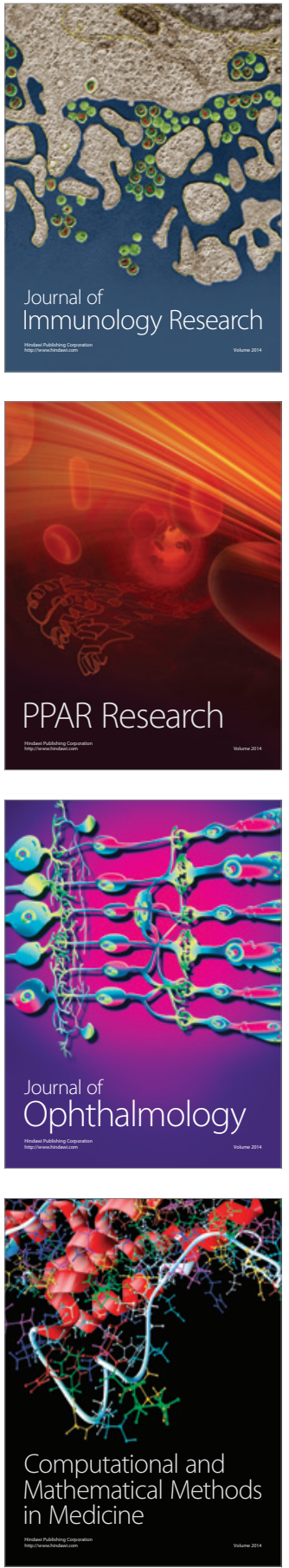

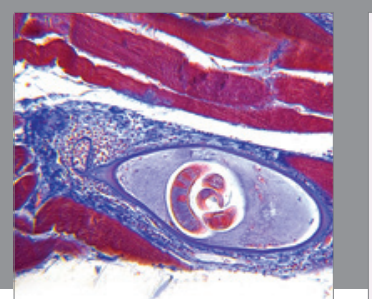

Gastroenterology Research and Practice

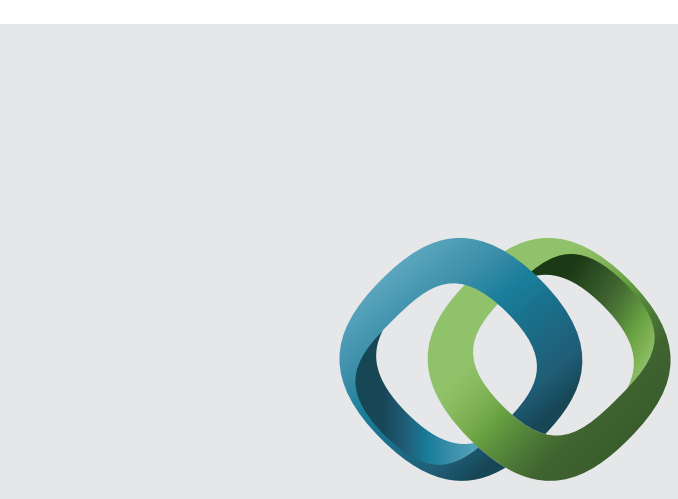

\section{Hindawi}

Submit your manuscripts at

http://www.hindawi.com
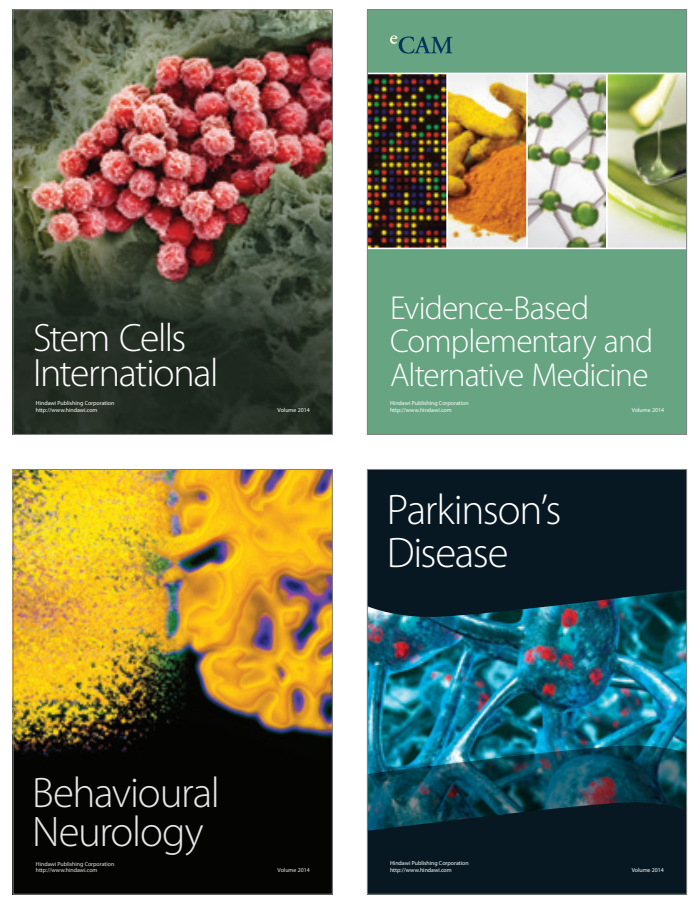
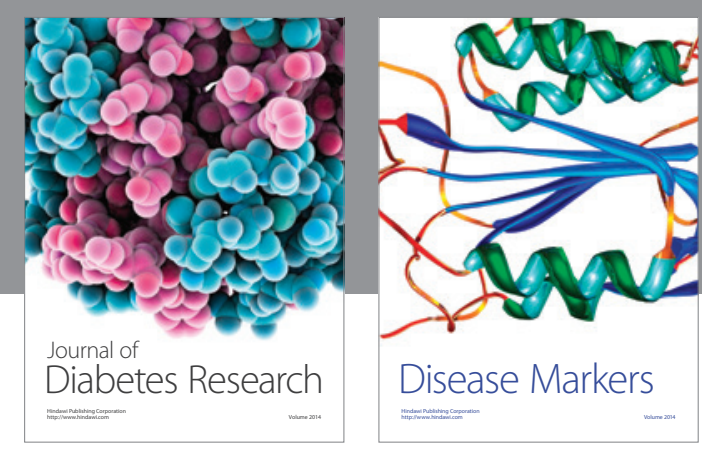

Disease Markers
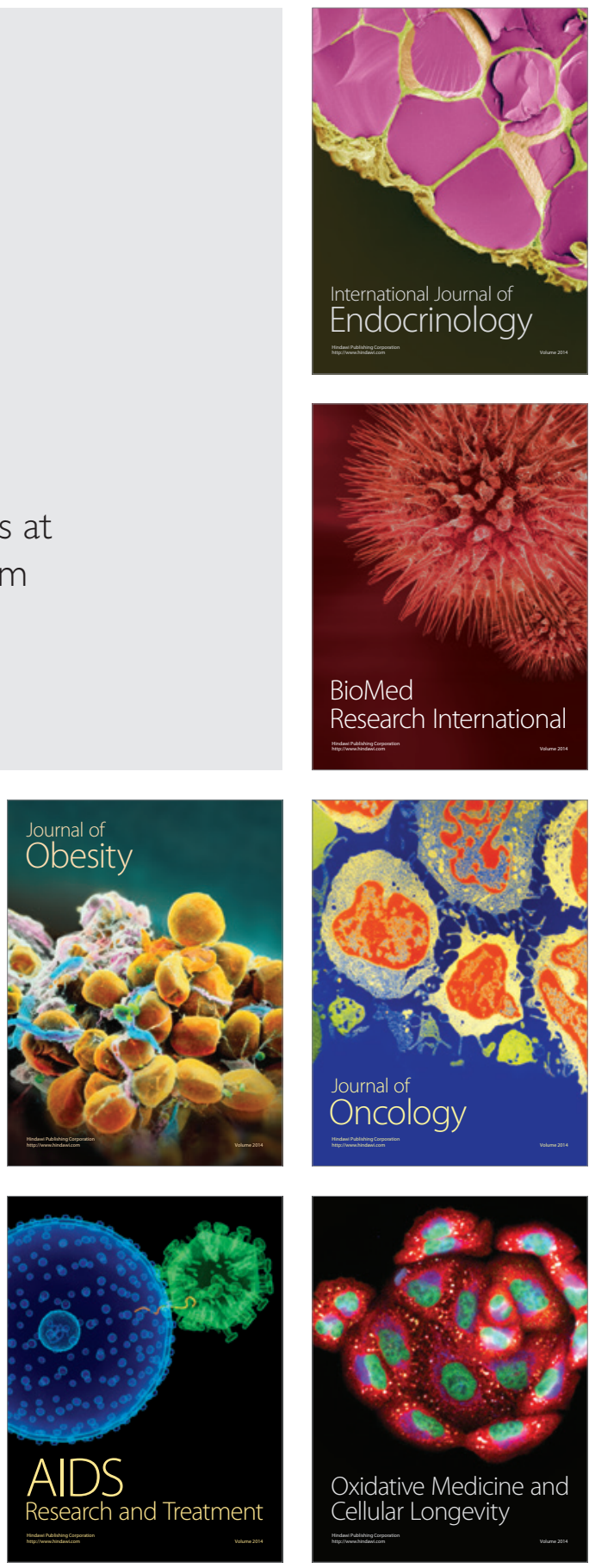